\title{
Mardin Kireçtaşının Yapı Malzemesi Olarak Kullanımına Yönelik Analizlerinin Yapılması: Kasımiye Medresesi Örneği
}

\author{
Fatih SEMERCi* \\ Necmettin Erbakan Üniversitesi, Mühendislik Mimarlık Fakültesi, Mimarlık Bölümü, 42140, Konya, \\ Türkiye. \\ *e-mail:fsemerci@gmail.com
}

Öz

Bu çalışmada, bir yapı taşı olarak kullanılan Mardin kireçtaşının özelliklerinin araştırılmasına yer verilmiştir. Bilindiği üzere Mardin yöresinden çıkarılan kireç taşları hakkında kapsamlı bir deneysel verilere dayanan çalışma yoktur. Bu nedenle Mardin kireçtaşının özellikleri hem literatür taraması ile hem deneysel analizlerle oluşturulmuştur.

Çalışmada, doğal taşlardan olan kireçtaşı hakkında genel bilgi verildikten sonra Mardin kireçtaşının özellikleri (fiziksel, kimyasal, mekanik, mikro yapı) araştırılmıştır. Bu aşamadan sonra Mardin tarihi yapılarından Kasımiye Medresesi hakkında bilgilendirme yapılmış ve bu yapılardan alınmış taş numunelerinin de fiziksel, kimyasal ve mekanik özellik deneyleri yapılmıştır.

Çalışmanın sonunda deneysel analizler ışığında, Kasımiye Medresesi’nden elde edilen taş örneklerinin birbiri ile karşılaştırması yapılmış ve bazı sonuçlar verilmiştir.

Anahtar Kelimeler: Mardin, Kasımiye Medresesi, yapı taşı, kireçtaşı, yapı taşı analizi

\section{A Study on Mardin Limestone as a Construction Component: Kasımiye Madrasah Example}

\section{Abstract}

In this study, the features of Mardin limestone as a construction component have been examined. As known, there is not any experimental data about Mardin limestone. In that case, the features of Mardin Limestone have been tasted through experimental analysis and data regarding.

In this study, after general information is given about limestone which is a natural deposit, characteristics (physical, chemical, mechanical) of Mardin limestone were researched. After this phase, data regarding Kasimiye Madrasah were collected which are historical places: besides pyhsical, mechanical, chemical experiments of sample of stones were carried out which were taken from this historical place.

At the end of this study and experimental analyses, limestone samples taken from Kasimiye Madrasah were compared each other and given some results.

Keywords: Mardin, Kasımiye Madrasah, building stone, limestone, building stone analysis.

\section{Giriş}

Yer kabuğundan çıkarılarak kullanılan endüstriyel hammaddeler içinde taşların önemli bir yeri vardır. Taş, tarihsel çağlar boyunca insan ile bütünleşen bir malzemedir. İnsan yaşamı, barınmadan korunmaya, duygularını, mesajlarını geleceğe aktarmadan, sonsuz yolculuğunda bedenini emanet etmeye kadar, sağlamlığın, güvenin simgesi olan taş ile iç içedir. Taş, ilkel insandan, günümüzün çağdaş insanına kadar insanın yaşamında şekil ve işlev değiştirerek sürekli kullanılagelmiştir (Yüzer, 1997). 21. yüzyılda da taşın çeşitli kullanımı devam etmekte ve sürekliliğini sürdürmektedir. Tarih 
boyunca taşın kullanımının devam etmesi, gelecekte de vazgeçilmez bir yapı malzemesi olacağını göstermektedir.

Taşların çeşitleri ve oluşum şekilleri kullanım alanlarını belirleyen etkenlerdir. Herhangi bir bölgede kullanılacak taş malzemesinin özellikleri, o taşın seçimini sağlamaktadır. Bu özelliklerden önemli olan bir tanesi ise taşın dayanımıdır. Taşın zamanla olası deformasyonlar ve doğal yıpranmalara karşı dayanıklıı̆ı̆ının derecesi taş seçimine bağlıdır. Mardin'de çıkarılan ve kullanılan kireçtaşının dayanımının gözlemlenmesi ise bu çalışmanın konusudur. Yöresel bir taş olup, tarih boyunca kullanımı süregelmiş Mardin kireçtaşının zamanla özelliklerinin değişimi ve dayanımı deneysel metotlar ve standartlar yardımı ile analiz edilmiştir.

\section{1. Çalışmanın Amacı}

Kireç taşlarının özellikleri hakkında pek çok bilgi literatürde yer almaktadır. Ancak Mardin yöresinden çıkarılan kireç taşları hakkında kapsamlı bir deneysel verilere dayanan çalışma bulunamamıştır. Bilindiği üzere Mardin yöresinden çıkarılan kireç taşları tarihi yapıları ile çok zengin olan bu kentimizin hemen hemen tüm yapılarında kullanılmıştır. Bu çalışmada Mardin tarihi yapılarında kullanılmış kireçtaşlarının özellikleri deneysel çalışmalarla analiz edilerek belirlenmiştir. Tarihi yapılardan alınan taşın özellikleri tespit edilmiş ve Mardin kireçtaşının daha bilinçli olarak kullanımına katkı getirmek amaçlanmıştır.

\section{Kireçtaşlarının Tanımlayıcı Özellikleri}

Bu bölümde kireçtaşlarının çeşitleri, sınıflandıııması, oluşumu, bileşimi ile fiziksel, kimyasal ve mekanik özellikleri aktarılmaya çalışılmıştır. Ayrıca kireçtaşlarının kullanım alanlarına değinilmiş, bölüm sonunda Mardin kireçtaşının özelliklerine genel olarak ele alınmıştır.

Yeryüzünde çeşitli jeolojik devirlerde oluşmuş değişik nitelikteki taşlar (püskürük, tortul, magmatik), pek çok faktörün etkisiyle ayrışır. Su, rüzgar, buzul ve canlıların etkisiyle yüksek yerlerden aşağılara doğru taşınır, belirli bir çökelme ortamında (sıcaklık ve basınç altında) toplanır ve üst üste birikirler. işte bu şekilde oluşmuş taşlara tortul taşlar (çökel veya sedimenter taşlar) denir. Kalker (kireçtaşı), bu taşlardan biridir (Yüzer,1997).

Doğal taşların, kimyasal tortul kayaçlar grubunda yer alan ve yoğunluk ve sertliklerine göre tebeşirden mermere kadar değişen, prehistorik döneme ait deniz yataklarında tabakalaşmış halde bulunan kireçtaşları, çok miktarda fosil ve deniz kabuğu içerirler. Bünyelerinde \%90'dan fazla kalsiyum karbonat, az miktarda da magnezyum karbonat bulunur ve bileşiminde yer alan magnezyum karbonat miktarı arttıkça, artışa bağlı olarak sırası ile dolomitik kireçtaşı, kireçli dolomit ve dolomit adını alırlar. Dokularına göre oolitik kireçtaşı, puzolitik kireçtaşı ve görünüşlerine göre de masif, gevşek, gözenekli gibi isimlerle sınıflandırılırlar. Kireçtaşları bileşimine giren yabancı maddelere göre de çeşitli renkler alırlar. Demir oksitle san ve kırmızı renk, mangan oksit, gri ve siyah organik maddeler ile de siyah ve mor renge sahip olurlar.

"Kalker" kelimesi aslında Fransızca kökenli bir kelimedir (calcaire). Türkçe karşılığı "Kireçtaşı"dır. Mineralojide adları geçen ve bileşimleri $\mathrm{CaCO} 3$ (kalsiyum karbonat) olan kalsit ve aragonitin şekilsiz türlerine "kalker" denir (Dinç, 2004).

Kireçtaşının dört ana özelliğine değinmek gerekirse;

- Kirecin ana hammaddesidir. İlk çağlardan beri elde edilmiş ve kullanılmış kireç, doğrudan kireçtaşının bir ürünüdür.

- Mermerlerin yapııı taşlarıdır. Başlangıçta kireçtaşı tabakaları ve serileri olan kayaç yığınları, metamorfizma geçirerek, yani yüksek basıncın, sıcaklığın ve geçen uzun zamanın etkisi ile değişerek mermere dönüşmüşlerdir.

- İlk insandan günümüze değin bütün evler, yollar ve köprülerde yani yapılaşmış tüm birimlerde en büyük oranda kullanılan madde kireçtaşıdır. 
- Çimento ve asfalt üretiminde $\% 60$ oranında ana hammadde olarak; beton dökümünde ve asfaltı yol yapımında ise çimento harcına ve asfalta karıştııılan mıcır olarak bol miktarda kullanılmaktadır (Gökaltun, 1997).

Yeraltı sularında travertenler şeklinde, deniz ya da tatlı sularda ise kimyasal, organik veya mekanik çökelme sonucu kalker yatakları oluşur. Oluşum süreçlerinden de anlaşılacağı üzere kalker 2 ana grupta toplanabilmektedir. Organik ve kimyasal kireçtaşları otokton, klastik kireçtaşları ise allokton olarak kabul edilmektedir. Yaygın olarak oluşan kireçtaşlarının çoğu organik ve kimyasal materyaller ihtiva etmektedir.

Kalsit (hegzagonal $\mathrm{CaCO}_{3}$ ) ve aragonit (ortorombik $\mathrm{CaCO}_{3}$ ) kristallerinin her ikisi de genç kireçtaşı oluşumlarında yer alabilmektedir. Aragonit kristallerinin kalsit kristallerine daha kolay dönüşebilmesi nedeniyle eski kireçtaşı oluşumlarında aragonit kristalleri bulmak güçtür (Meriçboyu, 1988).

Hidroklorik asitte $(\mathrm{HCl})$ köpürerek çözünür ve karbondioksit $\left(\mathrm{CO}_{2}\right)$ çıkarır. Bu, karbonatlı taşları diğer taşlardan ayıran en belirgin özelliktir (Erguvanlı, 1955).

$\mathrm{CaCO}_{3}+2 \mathrm{HCl}$------> $\mathrm{CaCl}_{2}+\mathrm{H}_{2} \mathrm{O}+\mathrm{CO}_{2}$ (köpürme)

\section{Mardin Yapılarının Genel Özelliği ve Kullanılan Malzeme}

Mardin'de ilk devirlerden beri kale içindeki mahallelere karşılık tepenin güney eteklerinde de mahalleler ve çarşılardan söz edilmektedir. Günümüzde tüm halk kalenin güneyinde yer alan eğimli arazide yaşamaktadır.

Mardin yapıları (son yıllarda modern mimari tekniği ile yapılan birkaç resmi ve özel yapı hariç) tamamen kesme taş malzeme ile yapılmıştır. Kullanılan taş, kuzeyde Diyarbakır bölgesindeki bazalta karşılık, güneyde açık renkli sarı kalker taşıdır. Kolay işlenen ve ocaktan çıktıktan bir süre sonra sertleşen bu kireçli oluşum Mardin yapılarının her devrinde aynı kolaylıkla kullanılmıştır. Taşın kolay işlenmesi ve yüzyıllardan beri yerleşip süregelen taş sanatı geleneği, Mardin yapılarında ahşap malzeme kullanımını engellemiştir (Altun,1971).

Mardin yapılarında katlar çeşitli tonoz şekilleriyle, genellikler çapraz tonozlarla payeler desteği ile meydana getirilmektedir. Hemen hemen tüm yapıların cephesi güneye, Mezepotamya ovasına doğru yönlenmeye sahiptir. Tepe yamacına kurulmuş yapılar, eğimden dolayı en az iki katlı olmaktadırlar. Kat tavanlarının meydana getirilişinde genellikle çapraz tonozların kullanıldığı yerlerde oldukça kalın payeler iki veya dört tonozu taşımaktadır. Bu durum anıtsal yapılarda daha farklı ve etkili bir durum meydana getirmektedir (Altun, 1971).

Geleneksel yapım teknolojisinin 1960'lara kadar sürdüğü Mardin'de, duvarların taşıyıcı olduğu yığma yapım ile ayak, sütun ve kemerlerin taşıyıcı olduğu iskelet yapımın birlikte kullanımı söz konusudur. Burada iskelet yapımdan özellikle söz edilmesi gerekmektedir. Geleneksel Mardin evinde modüler bir tasarım anlayışı vardır. Bu modülün sayısal olarak kesin tanımı yoktur. Değişken olmakla birlikte, $3.80 \times 3.80 \mathrm{~m}$., $4.00 \times 4.00 \mathrm{~m}$. gibi boyutlara üst katlarda sıkça rastlanmaktadır. Mardin evindeki modül boyutunun yapılanma alanına göre farklııklar gösterdiği ve daha doğru bir tanımla, kare ya da kareye yakın olduğu söylenebilir. Buna bağı olarak kapalı mekânlar için her mekân kendi modülünün bir çoğalmasıdır denilebilir. Özellikle üst katlarda her mekânın modüler bir açıklaması vardır. Eyvan ve revak gibi yan açık mekânlar da bir boyutlan ile bu açıklamanın içinde yer alabilmektedirler. Eyvan derinliği ve revak ön açıklığı, tasarımdaki birim modüle uygunluk göstermektedir. Düzgün sınırların olmadığı giriş katlarında ve bunun kısmen düzeltildiği üst katlarda modülasyonun egemenliği iskelet yapımın öne çıkmasına neden olmuştur (Alioğlu, 2000). 


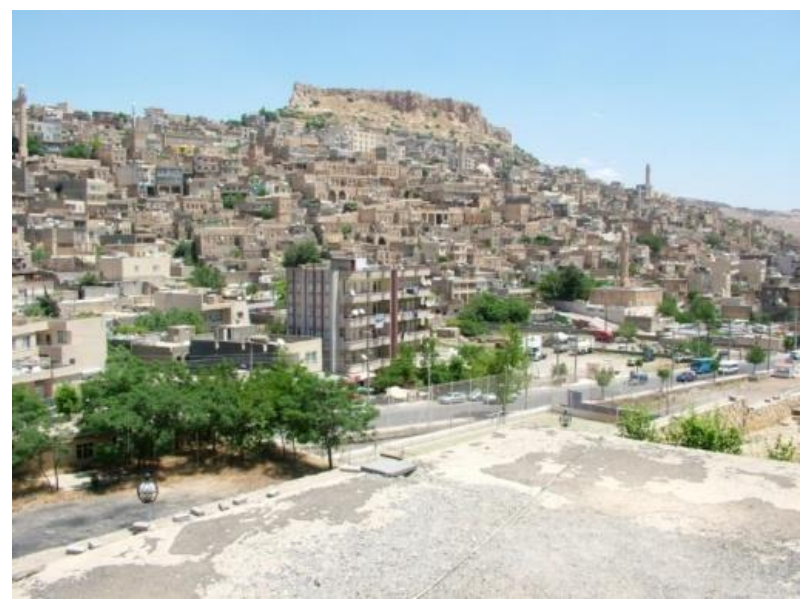

Şekil 1. Mardin Şehir Dokusu

Modüler yaklaşım, iskelet sistemin önemli bir parçasıdır. Geleneksel evlerdeki uygulamalarda bu izlenebilmektedir. Çoğunlukla giriş katlarında ahır, depo, mutfak gibi mekânlarda, büyük alanlara gereksinim duyulduğunda modülasyon ve iskelet sistem işbirliği içindedir. Ayaklar ve sütunlar kolon gibi, bunlar arasındaki bağlantıyı oluşturan kemerler de kiriş gibi çalışarak ve tonoz çeşitlerinden oluşan döşemenin yükünü alarak bir sistem oluşturmuşlardır. Modülün etken olduğu diğer mekânlarda ise, kimi kez asıl taşıyıcı olarak duvarlar yığma sistemin varlığını daha baskın kılabilmektedir. Örneğin iki modülden ibaret dikdörtgen yaşama biriminin tavanı, bütünsel olarak aynalı veya beşik tonoz olarak yapıldığında tek parça görünüm sunarak tartışmasız biçimde yığma sisteme referans vermektedir. Bu biçimlenmede modülasyonun var olup olmadığı ilk anda anlaşılamamaktadır. Ancak aynı birimin tavanı modüllere tekabül edecek gibi ayrı ayrı manastır tonozu yapıldığında, başka bir deyişle iki kare tavan ortaya çıktığında modülasyon tanınabilir olmaktadır. Bu özellikle de "L", "Ters T" tipi yaşama birimlerinde, eyvanda, revakta belirginleşmektedir (Alioğlu, 2000).

Geleneksel Mardin evinin asıl yapı malzemesi taştır. Taş, yapılarda dört biçimde kullanılııştır. Bunlardan biri taşın, kesme taş olarak örgüye girmesidir. Avluya ve terasa bakan bütün cepheler, tonoz başlangıç seviyesine kadar iç mekân duvarları, bazen de doğu, batı ve kuzey cepheleri kesme taş görünümündedir. Bir diğer taş çeşidi, kabaca yontularak örgüye sokulanıdır. Taş bu biçimi ile zemin kat avlu duvarı ve Mardin Ovası'na bakmayan cepheler gibi yerlerde kullanılmıştır. Bir diğer taş çeşidi olan moloz taş, çok önemli olmayan duvar yapımlarında, sandık duvar yapımında iç örgüde ve tonoz ya da kubbe örgüsünde tercih edilen bir taş türüdür. Taşın dördüncü hali ise bezeme amacı ile iç ve dış mekânlarda kullanıımasıdır. Her durumda da yakın çevrede ocaklarının oldukça bol bulunduğu sarı kalker taşı ana malzemeyi oluşturur. Ancak, yapıma giren ile bezeme olarak kullanılan taşlar, renk ve doku olarak birbirlerinden farklıdır. Strüktürel kullanımda açık sarı ve sert kalker, bezeme amaçlı kullanımda ise ocaktan çıktığında yumuşak olup işlenmesi kolay olan, fakat sonradan sertleşen koyu sarı kalker taşı tercih edilmiştir (Alioğlu, 2000).

Duvarlar moloz taş ve sandık duvar tekniği ile yapılmıştır. Moloz taş duvarlar genellikle yapının temel duvarlarında, giriş katında görünüme girmeyen bazı kısımlarda uygulanmıştır. Diğer bütün duvarlar, sandık duvar yapım tekniğinde, iç ve dış yüzleri düzgün kesme ya da kaba yontu, ortası moloz taş olarak inşa edilen duvar tipinde yapılmıştır. Duvar kalınlıkları giriş katlarında 0.8-2 metre, üst katlarda ise $0.75-0.90 \mathrm{~m}$. arasındadır. Taşıyıcı olmayan hela, teras, korkuluk duvarlarında ya da sonradan yapılan bölme duvarlarda 0.25-0.65 metre arasındaki ölçüler geçerlidir. Taşların akça geçmez biçimde derzsiz oluşturduğu duvar örgüsünde, çok ince bir harç ve kükürde batırılmış demir kenetler bağlayıcı olarak kullanılmıştır. Kesme taşın yüksekliği 0.21-0.25 metre arasında değişmekle birlikte, 0.22 ve 0.23 metre sık rastlanan bir ölçüdür. Görünüme giren taş hiçbir zaman sıvanmamıştır. Hatta bazen iç mekânlarda tavan örtüsü başlangıcına kadar düzgün kesme taş kullanılmıştır. 
Ayaklar düzgün kesme taş, sütunlar ise tambur taşı ile yapılmıştır. Giriş katlarında yer alan ayaklar, kare ya da dikdörtgendir (Alioğlu, 2000).

Kapalı, yarı açık ve açık bütün mekânların döşemeleri taştır. Ancak avlularda toprak, taş ya da her iki malzeme ile yapılmış döşeme örneklerine rastlanır. Son yüzyılda yalıtım işlevi olan bir cins şap geliştirilerek iç mekânlarda uygulanmıştır. Üst katların taş döşemeleri, bir alt katın tonoz çeşitlerini içeren tavanı üzerindedir. Tavanlar manastır tonozu, beşik tonoz, aynalı tonoz biçimindedir. Örnekleri az olmakla birlikte kubbeye de rastlanmaktadır (Alioğlu, 2000).

\section{Kasımiye (Sultan Kasım) Medresesi}

Mardin'in güneybatısındaki tepenin altında bulunan Kasımiye Medresesi'nin yapımına Artuklu döneminde başlanmış, Sultan Kasım tarafından da 1487-1502 yıllarında tamamlanmıştır. Medresenin yapım tarihi bilinmemektedir. Akkoyunlu Hükümdarı Cihangiroğlu Kasım Mardin'i onarmak için geniş bir çalışma başlatmış, bazı yapıların yanı sıra medreseler de yaptırmıştır (Altun, 1971).

Kasımiye Medresesi XIV. yüzyıl Artuklu mimari özelliklerini yansıtmaktadır. Kesme taş ve yumuşak yöresel taştan yapılan medresenin giriş kapısı sol tarafa kaydırılmıştır (Şekil 2). Bezemesi Zinciriye Medresesi ile yakınlık göstermektedir. Kapının dışında mukarnaslı bir kuşak, içeride köşe sütunları ve üç dilimli bir kemer bulunmaktadır. Bu kapıdan üzeri kubbe ile örtülü bir girişten beşik tonozlu koridora geçilmektedir. Bu koridordan avluya ve camiye ulaşılmaktadır (Göyünç, 1969).

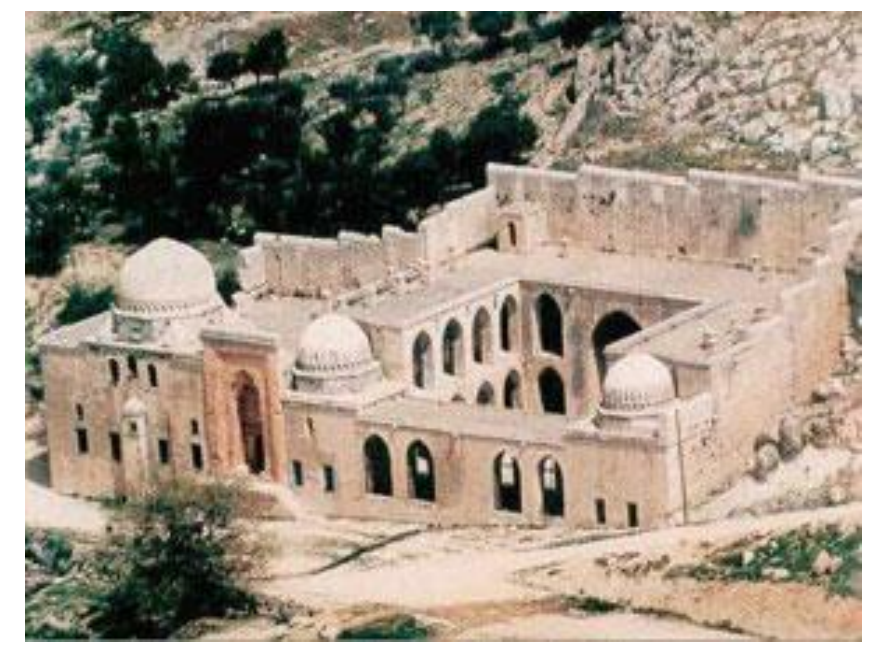

Şekil 2. Kasımiye Medresesi, Solda Kubbesi ile Camii Sağda Portal (Alioğlu, 2000)

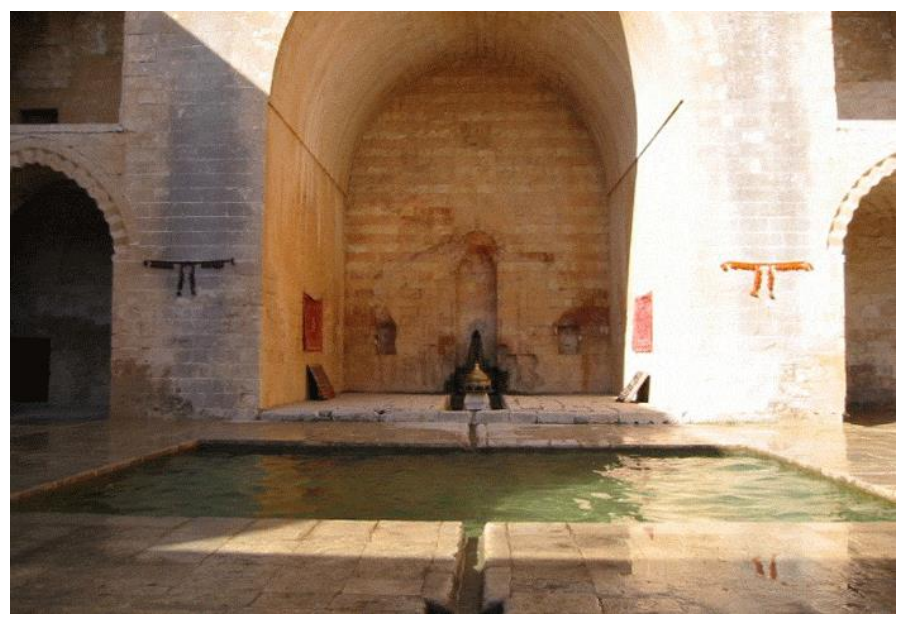

Şekil 3. Medrese'nin Avlusundaki Havuzlu Eyvan, (Alioğlu, 2000)

Cami üzeri kubbeli kare bir mekân ile yanlarındaki beşik tonozlu mekânlardan meydana gelmiştir, (Şekil 4). Avlunun arkasında üç yöne doğru uzanan medrese odaları sıralanmıştır. Revakların güneyinde dilimli kubbeleri ile dikkati çeken türbeler bulunmaktadır. Ayrıca avlunun kuzeyinde 
içerisinde havuz bulunan bir ana eyvan vardır (Şekil 3). Bu eyvanın iki yanına da beşik tonozlu birer oda yerleştirilmiştir (Altun, 1971) (Şekil 4).

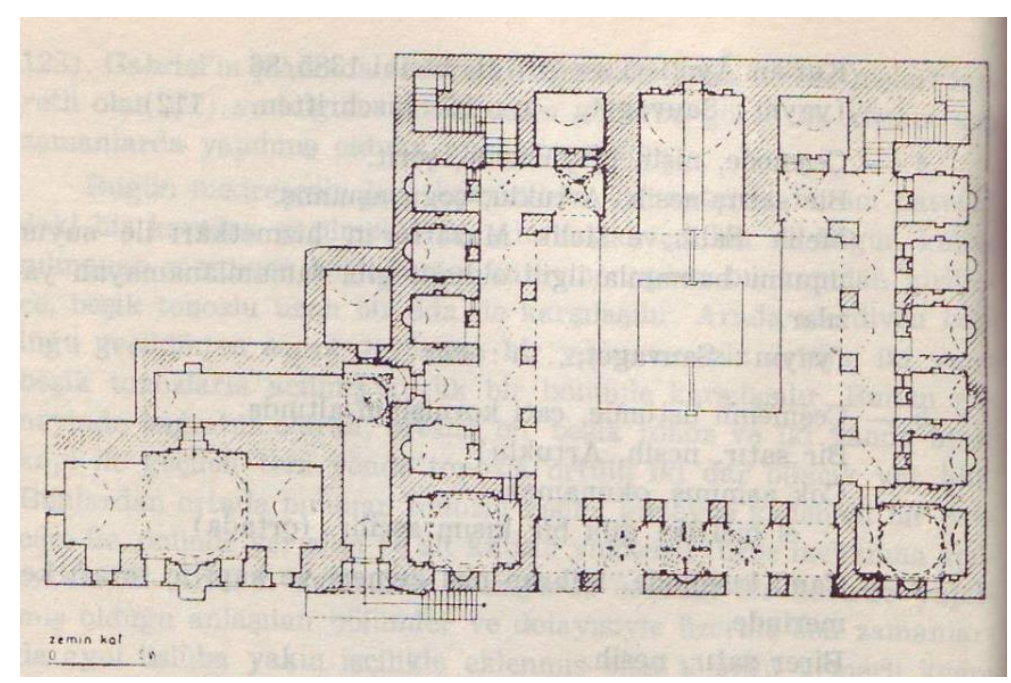

Şekil 4. Kasımiye Medresesi, Zemin Kat (Gabriel, 1933)

Yapının güney cephesi; batıda, büyük kubbenin altındaki cami kısmının pencere ve üstü dilimlenmiş yarım kubbe ile örtülü duvar payandası ile onun hemen yanında yer alan anıtsal portal nişi, doğuya doğru da iki dilimli kubbeli türbe mekânı arasında dışa açılan avlu revaklarının sivri kemerleri ile bütünlük arz etmektedir. Cephede en önemli bölümlerden olan portal Sultan İsa (Zinciriye) medresesinin portalini tekrarlamaktadır. Taşları ve taş süslemeleri oldukça aşınmış olan portal, iki sıra mukarnaslı dikdörtgen bir çerçeve içine alınmıştır. Üç dilimli büyük kemeri taşıyan sütunceler altlarda hafifçe yivlenmiş, yukarılarda ise örgülü profillerle işlenmiştir. Mukarnas dolgulu nişin içinde iki yanda iri rozetlerin sadece bir kısım kalıntısı seçilebilir. Cephede kapı kirişi üzerinde iki farklı taş iş̧̧iliği şeridinden de çok az şey kalmıştır. Anlaşılabildiği kadarı ile burada da üstte küçük kakma parçalarla bir geçme dekoru, altta da Sultan İsa (Zinciriye) Medresesi'nde aynı yerde görülen karşılıklı kakma palmetlerin daha sık şekilde uygulandığı bezeme yer alıyordu (Göyünç, 1969).

Yapının tarihini verebilecek hiçbir kitabe bulunmadığından ve kayıtlarda da ipucuna rastlanmadığından Gabriel'in ileri sürmüş olduğu ve benimsenen görüşe göre (Gabriel, 1933) yapımına Artuklu hâkimiyetinin sonlarında belki de Sultan İsa devrinde Zinciriye Medresesinin yapımından hemen sonra muhtemelen aynı mimar tarafından başlanmış, fakat Timur istilâsı ve Akkoyunlu baskısı gibi karışık bir durumun Mardin siyasetine hâkim olmağa başlaması üzerine yarım kalmış, daha sonra belki Akkoyunlular tarafından tamamlatıldığından Cihangir'in oğlu Kasım (893-908) 1457-1502 adına anılmıştır (Gabriel, 1933).

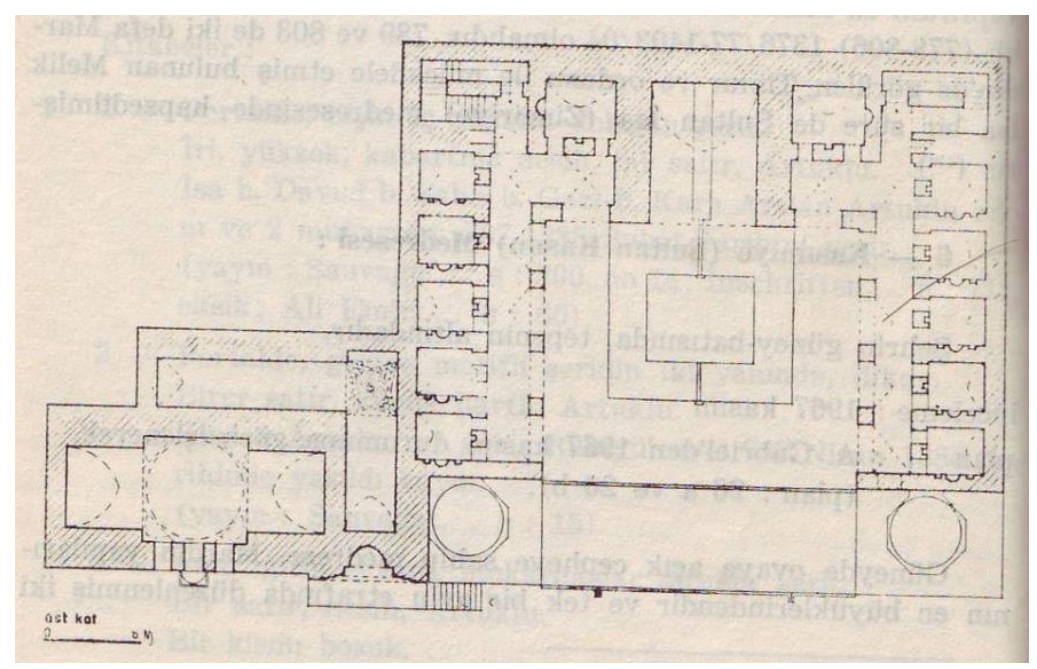

Şekil 5. Kasımiye Medresesi Üst Kat (Gabriel, 1933) 
Yerli geleneğin de bu şekilde andığı yapının Artuklu devrinde başlanıp, önemli kısmının bitirilmiş olduğu anlaşılmaktadır. Plan özellikleri, taş iş̧̧iliği, süsleme motifleri gibi Mardin için devir sınırlarına pek saygılı olmayan faktörleri de göz önüne alarak bu anıtsal yapının yine de Mardin'deki Artuklu devrinin sonuna konulması mümkündür (Alioğlu, 2000).

Yapı "zaviye ve mescid", "medrese ve zaviye" olarak Osmanlı devri kayıtlarına geçmiştir. İlk Dünya Savaşı'na kadar çalışmaya devam etmiş olan medrese XVI. yüzyılda Mardin'deki vakıfları en zengin ve geliri en fazla olan kuruluştu (Göyünç, 1969).

\subsection{Kasımiye Medresesi Numunelerinin Deneysel Analizi}

Kasımiye Medresesi'nden elde edilen taş örneklerinin fiziksel, mekanik ve ince yapı deneyleri yapılmıştır. Deneysel analizleri yapılan taş örnekleri Kasımiye Medresesi'nin zemininden elde edilmiştir (Şekil 6).

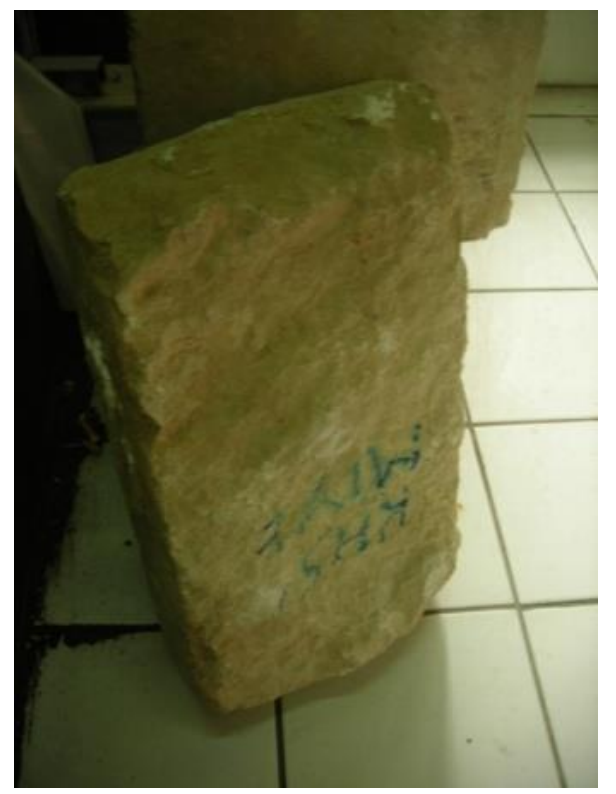

Şekil 6. Kasımiye Medresesi'nden alınan taş örneği

Blok halinde gelmiş olan numunelere $\mathrm{K}$ kodu verilerek deney numuneleri hazırlanmıştır. Bu kodlama sistemi Çizelge 1'de verilmiştir.

Çizelge 1. Taş örneklerinin kodlama sistemi

\begin{tabular}{|l|l|}
\hline Kod No & Tanım \\
\hline K & Kasımiye Medresesi'nden Alınan Deney Numuneleri \\
\hline
\end{tabular}

\subsection{Analiz Yöntemleri}

Mardin kireçtaşının zaman içinde özelliklerindeki değişimi analiz edebilmek için tarihi yapılardan alınan kireçtaşı örnekleri karşılaştırmalı olarak incelenmiştir. Bu incelemede örneklerin fiziksel, mekanik ve kimyasal özellikleri araştırılmıştır. Elde edilen sonuçlar karşılaştırılmış ve değerlendirilmiştir.

\subsubsection{Fiziksel özellik tayini deneyleri}

Fiziksel özellik tayini için; kılcal su emme katsayısı, atmosfer basıncı altında su emme oranı, su emme ve kuruma hızları, birim hacim kütlesi, özgül kütlesi ve su buharı geçirgenlik direnç faktörü vb. gibi büyüklükler bulunmuştur (Kocataşkın, 2000).

\subsubsection{Kılcal yolla su emme}

Kılcal yolla su emme tayini için TS EN 1925 (TS EN 1925, 2000) standardından yararlanılmıştır. Bunun için taş numuneleri, bir gün süre ile 105 드 etüvde bekletilmiş ve değişmez kütleye geldikten sonra 
desikatöre konularak soğutulmuş, daha sonra bir gün süre ile ortama bırakılmıştır. Kılcalıı deneyinde, yalnızca taban alanlarından kılcallık yoluyla emdirilen suya bağlı ağılık artışları, 1'den 14'e kadar her dakikanın katları şeklinde bir zaman diliminde, tartılmış ve aşağıdaki formül yardımı ile kılcalıı katsayısı bulunmuştur.

Kılcallık katsayısı formülü:

$$
\mathrm{N}=\frac{\mathrm{Q}}{\mathrm{A} \cdot \sqrt{\mathrm{t}}}
$$

Formülde;

$\mathrm{N}$ : Taşların kılcallık katsayısı (g/ $\mathrm{m}^{2}$ vdak)

Q: Birim zamanda geçen su miktarı (g)

A: Numunelerin suya değen taban alanları $\left(\mathrm{m}^{2}\right)$

T: Numunelerin suyla temas ettiği süre (dakika)'dır.

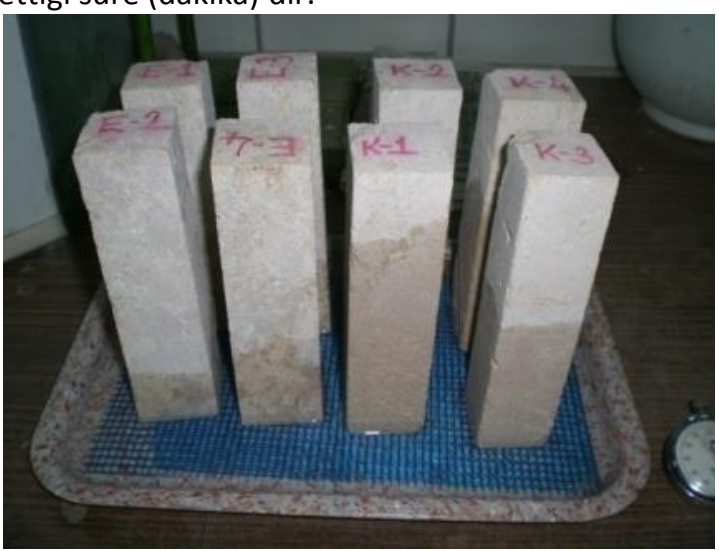

Şekil 7. K numunelerinin kılcallık deneyi.

Bu açıklamalar ışığında Kasımiye Medresesi numunelerinin kılcallık değerleri aşağıdaki çizelgelerde gösterilmektedir (Çizelge 2).

Çizelge 2. K Numunelerinin kılcallık katsayıları.

\begin{tabular}{|l|l|}
\hline Numune & Kılcallık katsayısı $\left(\mathrm{g} / \mathrm{m}^{2}\right.$. Vdk) \\
\hline K-1 & 1940,58 \\
\hline K-2 & 1882,34 \\
\hline K-3 & 952,87 \\
\hline K-4 & 1582,58 \\
\hline Ortalama & 1589,59 \\
\hline
\end{tabular}

\subsubsection{Atmosfer basıncı altında su emme oranı}

TS 699 (TS 699, 1976) standardında belirtildiği gibi, deney numuneleri temizlendikten sonra $20 \pm 5^{\circ} \mathrm{C}^{\prime}$ de su dolu bir kapta yüksekliğinin 1/4'üne kadar suya daldırıp, 1 saat bekletilmiş daha sonra 1'er saat $2 / 4$ ve $3 / 4^{\prime}$ ü suda bekletilmiş ve üzeri $1,2-2 \mathrm{~cm}$ su ile örtülerek 45 saat suda bekletildikten sonra 0,1 $\mathrm{g}$ hassasiyetle tartılmıştır. Bu işlemden sonra Arşimet terazisinde su içinde tartılmış ve aşağıdaki formüller ile kütlece ve hacimce su emme oranları hesaplanmıştır. 
Kütlece Su Emme Oranı:

$S k=\underline{G d-G k} \cdot 100(\%)$

Gk

Hacimce Su Emme Oranı:

$S h=G \underline{d-G k} \cdot 100(\%)$

$\mathrm{Gd}-\mathrm{Gds}$

Formülde;

Gd: Suya doymuş ağırlık, (g)

Gk: Kuru ağırlık, (g)

Gds: Su içindeki ağırlık, (g)

Sk: Kütlece su emme oranı, (\%)

Sh: Hacimce su emme oranı, (\%)'dir.

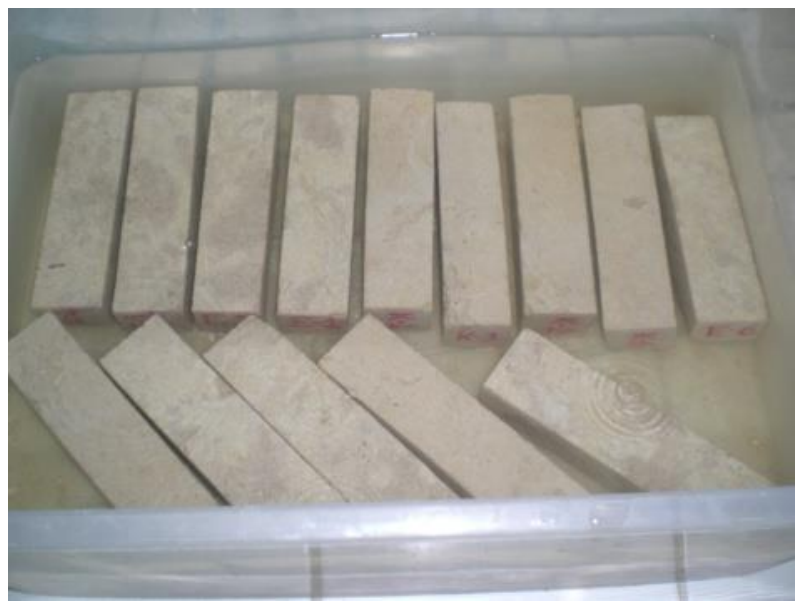

Şekil 8. K numunelerinin su emme deneyi

K numunelerinin su emme değerleri ile ilgili yüzde oranları Çizelge 3'te gösterilmiştir.

Su emme değerlerinde, numuneler arasındaki farklarda temel sebep numunelerin bünyesinde sahip olduğu sert bölümlerden kaynaklanmaktadır. Bu bölümlerin fazla olması su emme oranını ters yönde etkilemektedir. Buna ek olarak $\mathrm{K}$ numunelerinin tüm su emme değerleri yüksektir normal taş değerlerinden daha yüksek görünmektedir (Çizelge 3).

Çizelge 3. K numunelerinin su emme yüzdeleri

\begin{tabular}{|l|l|l|l|l|}
\hline $\begin{array}{l}\text { Numune } \\
\text { No }\end{array}$ & Sk(\%) & Sh(\%) & Skk(\%) & Skh(\%) \\
\hline K-1 & 9,75 & 19,97 & 16,44 & 33,42 \\
\hline K-2 & 8,72 & 18,27 & 15,45 & 32,56 \\
\hline K-3 & 8,33 & 17,70 & 15,96 & 33,75 \\
\hline K-4 & 8,29 & 17,61 & 14,47 & 31,07 \\
\hline K-5 & 8,42 & 17,59 & 15,75 & 33,05 \\
\hline K-6 & 6,87 & 14,92 & 13,36 & 27,31 \\
\hline Ortalama & 8,40 & 17,68 & 15,24 & 31,86 \\
\hline
\end{tabular}

\subsubsection{Su emme ve kuruma hızlarının tayini}

Tüm deneylerde olduğu gibi numuneler, etüvde değişmez kütleye gelinceye kadar kurutulmuş, desikatörde soğutulduktan sonra, $20^{\circ} \mathrm{C}$ deki suyun içine tamamen daldırılıp, 1, 2, 3, 6, 24, 48 ve 72.saatlerdeki ağırlık artışları yüzde olarak hesaplanmış ve buna göre bir grafik çizilmiştir. Bu işlem bitiminde aynı numuneler sudan çıkarılmış ve laboratuvar ortam şartlarına maruz bırakılarak aynı 
sürelerde kuruma hızına bağlı olarak ağılık düşüşleri yüzde olarak belirlenmiştir. Su emme ve kuruma grafikleri, zamana bağıı olarak çizilmiştir (Borelli, 1999).

K numunelerinin su emme ağırlıkları ve grafikleri Çizelge 4 ve Şekil $9^{\prime}$ da verilmiştir.

Çizelge 4. K numunelerinin zamana bağlı su emme oranları (\%)

\begin{tabular}{|l|l|l|l|l|l|l|l|}
\hline $\begin{array}{l}\text { Numune } \\
\text { No }\end{array}$ & 0 saat & 1.saat & 2.saat & 3.saat & 6.saat & 24.saat & 48.saat \\
\hline K-1 & 0 & 7,99 & 8,13 & 8,23 & 8,43 & 8,93 & 9,46 \\
\hline K-2 & 0 & 7,38 & 7,46 & 7,51 & 7,72 & 8,16 & 8,70 \\
\hline K-3 & 0 & 6,95 & 6,99 & 7,04 & 7,24 & 7,58 & 8,03 \\
\hline K-4 & 0 & 6,86 & 6,89 & 6,96 & 7,08 & 7,50 & 8,01 \\
\hline K-5 & 0 & 7,08 & 7,21 & 7,24 & 7,44 & 7,79 & 8,40 \\
\hline Ortalama & 0 & 7,25 & 7,33 & 7,39 & 7,58 & 7,99 & 8,52 \\
\hline
\end{tabular}

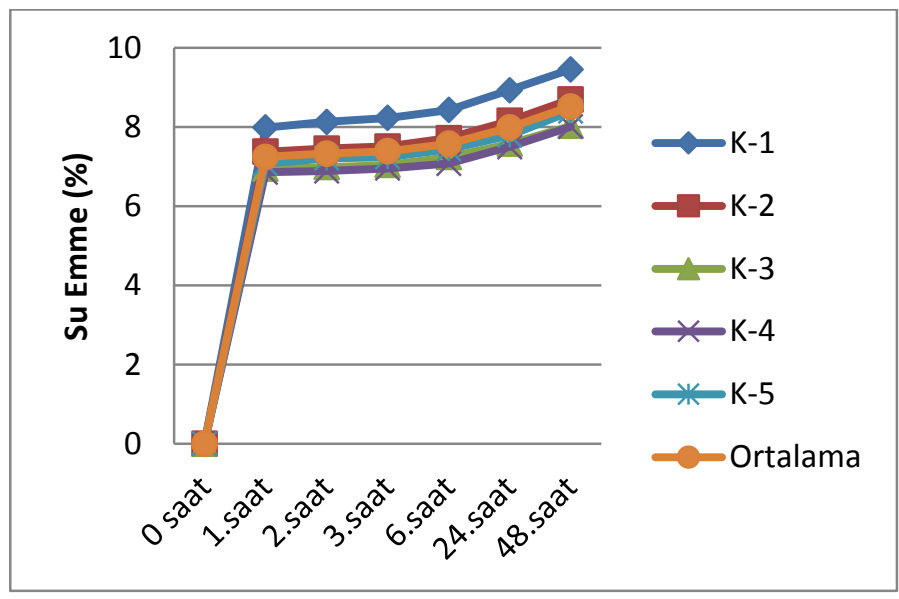

Çizelge 9. Numunelerin su emme grafiği

K numunelerinin kuruma ağırlıkları ve grafikleri Çizelge 5 ve Şekil 13'te verilmiştir.

Çizelge 5. K numunelerinin zamana bağlı kuruma oranları (\%)

\begin{tabular}{|l|l|l|l|l|l|l|l|}
\hline $\begin{array}{l}\text { Numune } \\
\text { No }\end{array}$ & 48. saat & 24.saat & 6.saat & 3.saat & 2.saat & 1.saat & 0 saat \\
\hline K-1 & 9,04 & 5,98 & 3,03 & 0,29 & 0,18 & 0,04 & 0 \\
\hline K-2 & 8,45 & 4,27 & 1,53 & 0,45 & 0,31 & 0,15 & 0 \\
\hline K-3 & 7,51 & 4,27 & 1,89 & 0,31 & 0,18 & 0,03 & 0 \\
\hline K-4 & 7,32 & 2,72 & 1,29 & 0,58 & 0,33 & 0,16 & 0 \\
\hline K-5 & 8,15 & 3,94 & 1,53 & 0,32 & 0,19 & 0,13 & 0 \\
\hline Ortalama & 8,09 & 4,24 & 1,85 & 0,39 & 0,24 & 0,10 & 0 \\
\hline
\end{tabular}




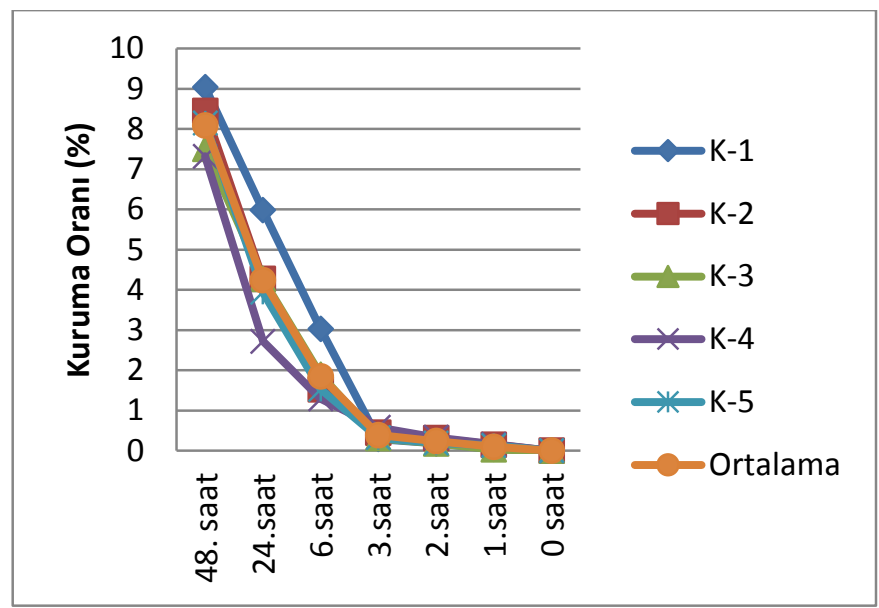

Şekil 10. Numunelerin kuruma grafiği

\subsubsection{Birim hacim kütlenin tayini}

TS 699 (TS 699, 1976) standardı esas alınarak yapılan deneyde numuneler $105^{\circ} \mathrm{C}^{\prime}$ ye kadar ısıtılmış etüvde değişmez kütleye kadar kurutulmuştur. Daha sonra desikatörde oda sıcaklığına kadar soğutulmuş olan numuneler, $0,1 \mathrm{gr}$. hassasiyetle tartılmıştır (Gk). Numunenin hacmi, suya doymuş ağırlık ve su içindeki ağırlığın farkına göre aşağıdaki formül yardımı ile bulunmuştur.

$\mathrm{dh}=\frac{\mathrm{Gk}}{\mathrm{V}}\left(\mathrm{g} / \mathrm{cm}^{3}\right)$

Formülde;

Gk: Numunenin kuru ağırlığı, (g)

V: Numunenin hacmi, $\left(\mathrm{cm}^{3}\right)$

dh: Birim hacim kütle, $\left(\mathrm{g} / \mathrm{cm}^{3}\right)^{\prime}$ dir.

Bu açıklamalar sonucunda yapılan deney sonrası numunelerin birim hacim kütle değerleri Çizelge 6'da verilmiştir.

Çizelge 6. K numunelerinin birim hacim kütlesi

\begin{tabular}{|l|l|}
\hline ÖRNEK & $\begin{array}{l}\text { dh } \\
\left(\mathrm{gr} / \mathbf{c m}^{\mathbf{3}}\right)\end{array}$ \\
\hline $\mathrm{K} 1$ & 2,05 \\
\hline $\mathrm{K} 2$ & 2,09 \\
\hline $\mathrm{K} 3$ & 2,12 \\
\hline $\mathrm{K} 4$ & 2,12 \\
\hline $\mathrm{K} 5$ & 2,09 \\
\hline K6 & 2,17 \\
\hline Ortalama & $\mathbf{2 , 1 1}$ \\
\hline
\end{tabular}

\subsubsection{5. Özgül kütlenin tayini}

TS 699 (TS 699, 1976) standardına uygun olarak önceden kurutulup, soğutulmuş malzeme numuneleri çok ince öğütülmüştür. Özgül kütle, $90 \mu$ elekten elenmiş toz numune ve distile su içeren piknometre yardımı ile aşağıdaki formül kullanılarak bulunmuştur.

do $=\mathrm{Gk}(\mathrm{g} / \mathrm{cm} 3)$

$\mathrm{V}$

do: Özgül kütle, (g / cm3)'dir.

K numunelerinin ayrı ayrı özgül kütle değerleri tayin edilmiştir. Bulunan değerler Çizelge 7 'de ifade edilmiştir. 


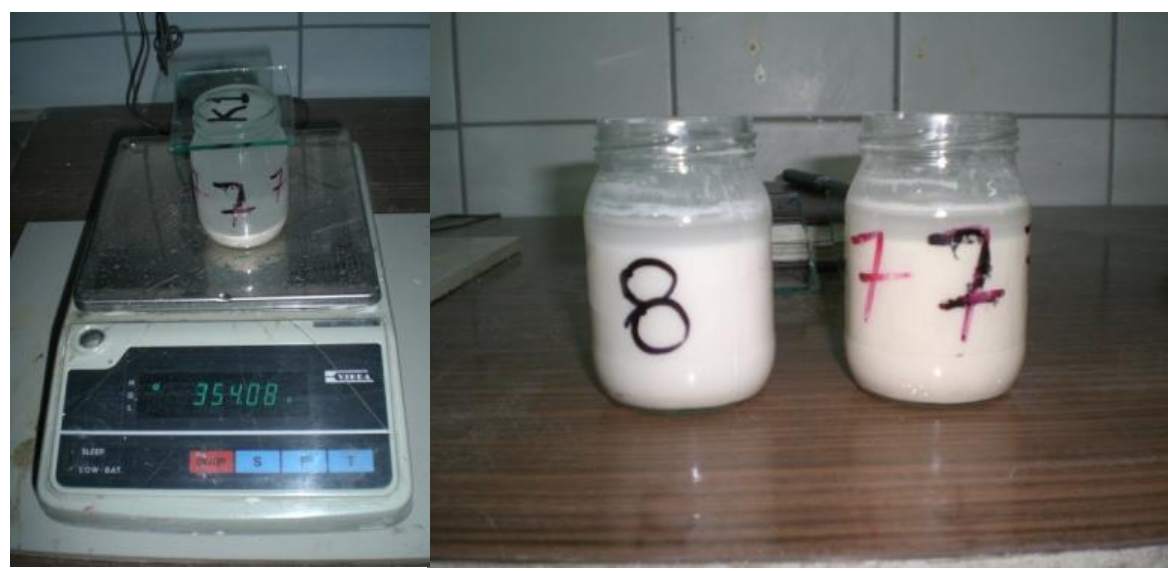

Şekil 11. Özgül kütle deneyi.

$\mathrm{Bu}$ deneyin yapımında $\mathrm{K}$ numunelerinin renklerinin farklı olduğu gözlemlenmiştir. $\mathrm{K}$ (Kasımiye Medresesi) numunesi renginin açık gri bir renk olduğu görülmüştür.

Çizelge 7. K numunelerinin özgül kütle sonuçları

\begin{tabular}{|l|l|}
\hline ÖRNEK & do(gr/cm $\left.\mathbf{c m}^{\mathbf{3}}\right)$ \\
\hline $\begin{array}{l}\text { K Örneğinin Özgül } \\
\text { Kütle Tayini }\end{array}$ & 2,72 \\
\hline
\end{tabular}

\subsubsection{Su buharı geçirgenlik deneyi}

Bu deney, DIN 52615 standardında tanımlanan kuru kap (dry cup) yöntemine göre yapılmıştır. Deneyde su emici malzeme olarak $\mathrm{CaCl} 2$ kullanılmıştır. Yaklaşık $7 \mathrm{~cm}$ 'lik çapa sahip numunelerin, çapları ve kalınlıkları 6 farklı yerinden ölçülerek ortalamaları alınmıştır. Böylece numunelerin çap ve kalınlık (d) değerleri bulunmuştur. Bu deney, 20-23oC sıcaklıkta ve \%90-99 bağıl nemde sabitlenen desikatör ortamında yapılmış, numunelerin ağırlık değişimleri her gün aynı saatte ve 5 haneli hassas terazi yardımıyla ölçülmüştür. Bu deney 1,5 ay sürdürülmüştür ve buna göre örneklerin aşağıdaki formül yardımı ile su buharı geçirgenlik direnç katsayısı $(\mu)$ hesaplanmıştır.

$\mu=1 / d(O H \times A x[(P 1-P 2) / G]-d H)$

Formülde;

$\mathrm{d}$ : Numunenin kalınlığı $(\mathrm{m})$

BH: Havanın su buharı iletkenliği

A: Numunenin alanı $\left(\mathrm{m}^{2}\right)$

P: Su buharı basınç değerleri (Pascal)

G: Geçen su buharı miktarı $(\mathrm{kg} / \mathrm{h})$

$\mathrm{dH}$ : Numune altında kalan havanın kalınlığı $(\mathrm{m})$

$B H=(0,083 / R B x T) \times(P o / P h) \times(T / 273) 1.88$

Formülde;

$\mathrm{T}$ : ${ }^{\circ} \mathrm{K}$ cinsinden sıcaklık

$\mathrm{Ph}:$ Ortalama hava basıncı

Po: Normal atmosfer basıncı'dır. 


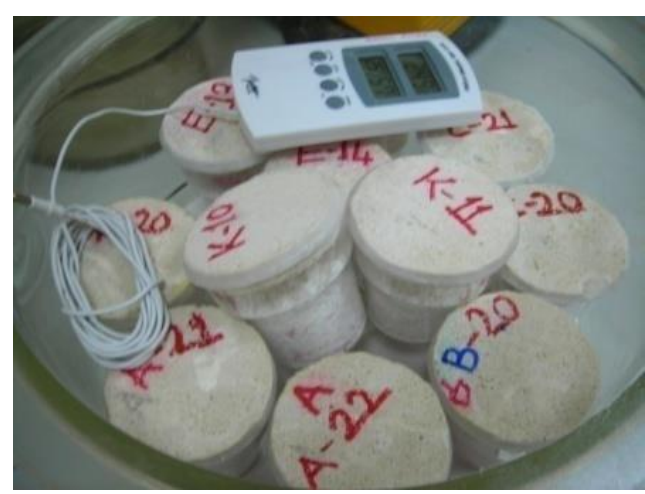

Şekil 12. Su buhar geçirgenlik deneyi

K numunelerinin buhar geçirgenlik katsayıları Çizelge 8'de gösterilmiştir.

Çizelge 8. Numunelerin su buhar geçirgenlik katsayısı

\begin{tabular}{|l|l|}
\hline Numune & $\begin{array}{l}\text { Buhar geçirgenlik katsayısı } \\
(\boldsymbol{\mu})\end{array}$ \\
\hline K-10 & 80,84 \\
\hline K-11 & 50,71 \\
\hline Ortalama & 60,77 \\
\hline
\end{tabular}

\subsubsection{Fiziksel özellik deney sonuçları}

Kasımiye Medresesi'nin fiziksel özellikleri çizelgeler halinde gösterilmiştir (Çizelge 9). Buna göre Kasımiye Medresesi'nin yoğunluk ve özgül kütle değerleri, su emme oranları yüksektir. Aynı şekilde kılcallık katsayısında da Medrese taşının değeri yüksektir. Medrese taş numunesinin asit kaybı \% 81'dir. Bu durum Medrese taşının kil içeriğinin normal bir taşa göre daha fazla olduğunu göstermektedir.

Çizelge 9. Kasımiye Medresesi örneklerinin fiziksel özellikleri

\begin{tabular}{|c|c|c|c|c|c|c|c|c|c|}
\hline ÖRNEK & $\begin{array}{l}\text { Sk } \\
\text { (\%) }\end{array}$ & $\begin{array}{l}\text { Sh } \\
\text { (\%) }\end{array}$ & $\begin{array}{l}\text { Skk } \\
\text { (\%) }\end{array}$ & $\begin{array}{l}\text { Skh } \\
\text { (\%) }\end{array}$ & $\begin{array}{l}\mathrm{dh} \\
\left(\mathrm{gr} / \mathrm{cm}^{3}\right)\end{array}$ & $\begin{array}{l}\text { do } \\
\left(\mathrm{gr} / \mathrm{cm}^{3}\right)\end{array}$ & $\begin{array}{l}\text { Porozite } \\
\text { (\%) }\end{array}$ & $\begin{array}{l}\text { Doymuşluk } \\
\text { Derecesi } \\
\text { (\%) }\end{array}$ & $\begin{array}{l}\text { Kılcallık Katsayısı } \\
\text { (gr/m² Vdak.) }\end{array}$ \\
\hline K1 & 9,75 & 19,97 & 16,44 & 33,42 & 2,05 & \multirow{6}{*}{2,72} & 25 & 75 & 1940,58 \\
\hline K2 & 8,72 & 18,27 & 15,45 & 32,56 & 2,09 & & 23 & 77 & 1882,34 \\
\hline K3 & 8,33 & 17,70 & 15,96 & 33,75 & 2,12 & & 22 & 78 & 952,87 \\
\hline K4 & 8,29 & 17,61 & 14,47 & 31,07 & 2,12 & & 22 & 78 & 1582,58 \\
\hline K5 & 8,42 & 17,59 & 15,75 & 33,05 & 2,09 & & 23 & 77 & \\
\hline K6 & 6,87 & 14,92 & 13,36 & 27,31 & 2,17 & & 20 & 80 & \\
\hline Ortalama & 8,40 & 17,68 & 15,24 & 31,86 & 2,11 & 2,72 & 22,5 & 77,5 & 1589,59 \\
\hline
\end{tabular}

\subsubsection{Mekanik özellik tayini deneyleri}

Mekanik özellik tayini için; tek eksenli yük altında eğilmede çekme deneyi (MPa), basınç dayanımı deneyi (MPa), dinamik elastisite modülü tayini deneyi (MPa) vb. gibi deneyler yapılmıştır (TS EN 1925, 2000). Bu deneylerde başta TS 699 (TS 699, 1976) standardı ve ilgili TS EN standartlarından yararlanılmıştır.

\subsubsection{Tek eksenli yük altında eğilmede çekme deneyi}

Eğilmede çekme dayanımını belirlemek için orta noktasından yüklenmiş basit kiriş metodu ile eğilmede çekme tayini deneyi yapılmıştır. Bu çalışmada mesnetler arası mesafe $100 \mathrm{~mm}$ alınmıştır. $4 \times 4 \times 16 \mathrm{~cm}$ boyutlarındaki deney numunesi, mesnetler üzerine ortalanacak şekilde yerleştirilmiştir. Kırılmanın olduğu andaki $P$ yükü presin göstergesinden okunmuştur. Okunan $P$ yükü, aşağıdaki formülde yerine konarak eğilme dayanımı hesaplanmıştır (TS EN 12372, 2003). 


$$
\mathrm{F}_{\mathrm{eg}}=\frac{3}{2} \times \frac{(\mathrm{Pk} \times 1)}{\mathrm{b} \times \mathrm{h}^{2}}
$$

Formülde;

Feğ:Eğilme dayanımı, ( $\left.\mathrm{N} / \mathrm{mm}^{2}\right)$

$\mathrm{P}$ : Deney presinden okunan kırılma anındaki yük, (N)

I: Yükleme tablası mesnetleri arası açıklık, (100 mm)

b: Kırılma kesitinin genişliği, $(40 \mathrm{~mm})$

h: Kırılma kesitinin yüksekliği, (mm)'dir.

K numunelerinin eğilme dayanımı değerleri Çizelge $10^{\prime}$ da gösterilmiştir.

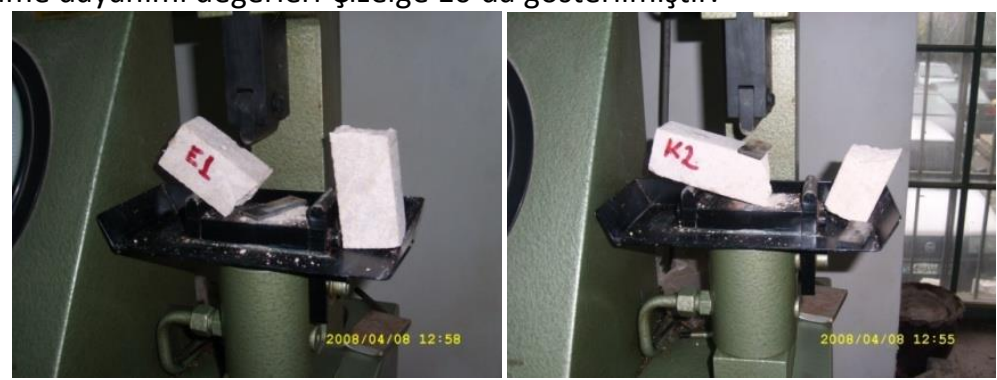

Şekil 13. Yük altında eğilmede çekme deneyi.

Çizelge 10. K Kireçtaşı örneklerinin eğilme dayanımları.

\begin{tabular}{|l|l|l|l|l|l|l|l|}
\hline Numune no & K-1 & K-2 & K-3 & K-4 & K-5 & K-6 & Ortalama \\
\hline Eğilme Dayanımı (N/mm²) & 2,94 & 4,05 & 4,4 & 6,77 & 2,65 & 3,56 & 4,06 \\
\hline
\end{tabular}

\subsubsection{Tek eksenli yük altında basınç dayanımı deneyi}

Eğilmede çekme deneyi uygulandıktan sonra ikiye bölünen numunelerde, basınç dayanımı tayini deneyi yapılmıştır. Her bir yarım numune, deney presinin yükleme başlıkları arasına yerleştirilerek yük uygulanmıştır. Yüklemeye sabit bir hızla ve darbe etkisi yapmayacak şekilde numune kırılıncaya kadar devam edilmiş ve kırılmanın olduğu anda, deney presinin gösterdiği en büyük yük kaydedilmiştir. Bu değer, kırılma yükü $(\mathrm{Pk})$ değerini vermektedir. Newton cinsinden Pk değeri aşağıdaki formülde yerine konularak, deneyi yapılan numunenin dayanabildiği maksimum basınç mukavemeti bulunmuştur (TS EN 1926, 2000).

Basınç dayanımı,

$F e=\frac{P k}{A}$

Formülde;

Fe: Basınç dayanımı, $\left(\mathrm{N} / \mathrm{mm}^{2}\right)$

Pk: Kırılma yükü, $(N)$

A: Yüklemenin yapıldığı kesit alanı, $\left(\mathrm{mm}^{2}\right)^{\prime}$ dır.

$\mathrm{K}$ numunelerinin basınç ve basınç dayanımı değerleri Çizelge $11^{\prime}$ de verilmiştir.

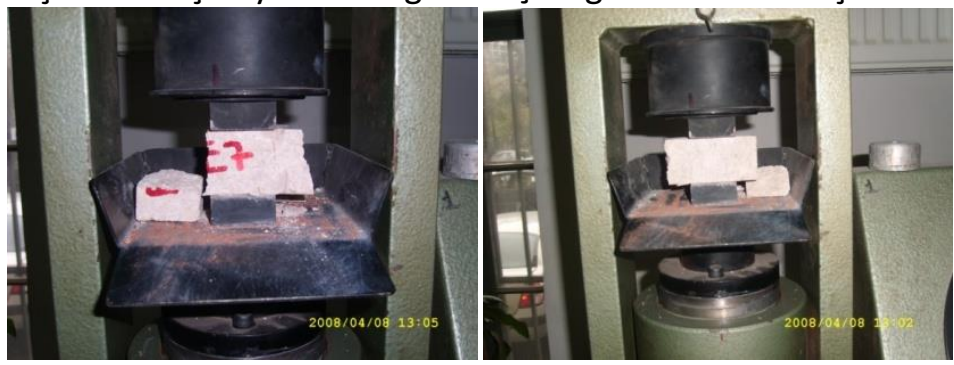

Şekil 14. Eğilmede kırılan parçalar üzerinde yapılan basınç dayanımı deneyi. 
Çizelge 11. K Kireçtaşı örneklerinin basınç dayanımları.

\begin{tabular}{|c|c|c|}
\hline Numune no & $\begin{array}{l}\text { 1. Parçanın } \\
\text { Basınç Dayanımı } \\
\left(\mathrm{N} / \mathrm{mm}^{2}\right)\end{array}$ & \begin{tabular}{|lr}
2. & Parçanın \\
Basınç & Dayanımı \\
$\left(\mathrm{N} / \mathrm{mm}^{2}\right)$ & \\
\end{tabular} \\
\hline $\mathrm{K}-1$ & 8,13 & 30,66 \\
\hline $\mathrm{K}-2$ & 9,37 & 36,85 \\
\hline $\mathrm{K}-3$ & 22,33 & 23,69 \\
\hline $\mathrm{K}-4$ & 16,99 & 25,49 \\
\hline K-5 & 16,99 & 18,35 \\
\hline $\mathrm{K}-6$ & 26,4 & 18,6 \\
\hline Ortalama & 16,7 & 25,6 \\
\hline
\end{tabular}

\subsubsection{Ultrases hızı tayini}

Ultrases hızlarının belirlenmesi için WTW DIGı EG-C2 modeli ultrases cihazı kullanılmıştır. Bu cihaz ile numunelerin iki ucuna cihazın alıcı ve verici probları yerleştirilerek ses geçiş süresi $(T, \mu s n)$ ölçülmüş, numunelerin uzunlukları dikkate alınarak aşağıdaki formül yardımı ile ses geçiş hızları (Vo) hesaplanmıştır. Bu deneyde, TS EN 14579, Doğal Taş Deney Metotları-Ses Hızının İlerlemesinin Tayini isimli standarttan yararlanılmıştır.

$V o=\frac{L}{T}$

Formülde;

Vo=Ultrases hızı, (km/sn)

$\mathrm{L}=$ Numunenin uzunluğu, $(\mathrm{mm})$

T= Zaman, ( $\mu \mathrm{sn})^{\prime}$ 'dır.

Ultrases hızı sonuçları yukarıdaki formüle göre hesaplanmış ve aşağıdaki çizelgede gösterilmiştir (Çizelge 12).

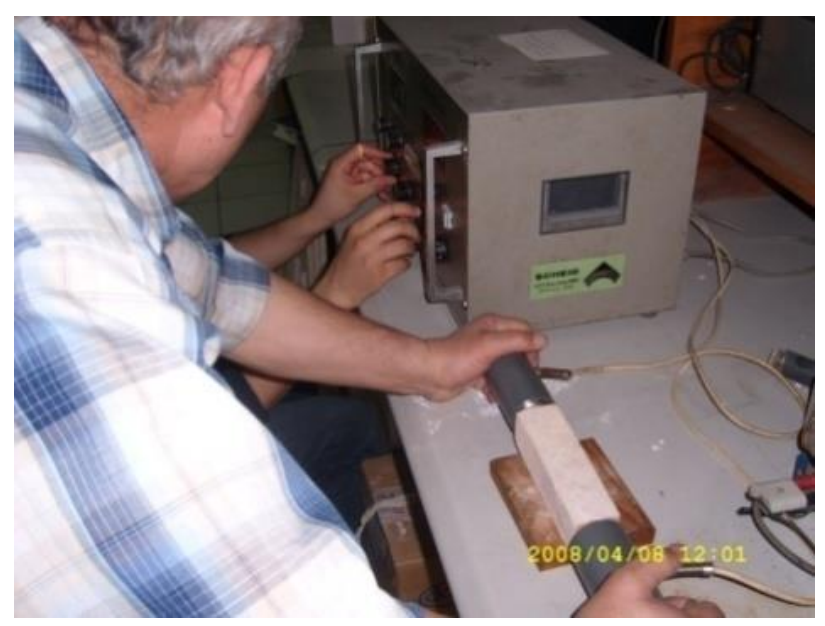

Şekil 15. Ultrases hızı tayini.

Çizelge 12. K (Kasımiye Medresesi) numunelerinin ultrases hızları

\begin{tabular}{|l|l|l|l|l|l|}
\hline Numune No & $\mathbf{a}(\mathbf{m m})$ & $\mathbf{b}(\mathbf{m m})$ & $\mathbf{I}(\mathbf{m m})$ & to $(\boldsymbol{\mu s})$ & $\begin{array}{l}\text { Vo } \\
\mathbf{( k m} / \mathbf{s})\end{array}$ \\
\hline K-1 & 39,96 & 41,5 & 155,6 & 61 & 2,55 \\
\hline K-2 & 40,03 & 40,48 & 155,67 & 62 & 2,51 \\
\hline K-3 & 36,94 & 41,18 & 155,36 & 59 & 2,63 \\
\hline K-4 & 41,2 & 39,18 & 154,98 & 54 & 2,87 \\
\hline K-5 & 36,79 & 41,89 & 155,27 & 63 & 2,46 \\
\hline K-6 & 41,67 & 38,83 & 156,96 & 55 & 2,85 \\
\hline Ortalama & & & & 59 & 2,65 \\
\hline
\end{tabular}




\subsubsection{Dinamik elastisite modülü tayini}

DIGI EG-C2 modeli ultrases cihazı kullanılarak, yapı numunelerinde bulunan ultrases hızları ve numunelerin yoğunluk değerleri kullanılarak aşağıdaki formül ile dinamik elastisite modülü değerleri hesaplanmıştır. Bu deneyde, TS EN 14146 Doğal Taşlar Deney Metotları-Dinamik Elastisite Modülünün Tayini standardından yararlanılmıştır.

$\mathrm{Eu}=\mathrm{Vo} 2 \times \operatorname{dox} 103\left(\mathrm{~N} / \mathrm{mm}^{2}\right)$

Vo=Ultrases hızı, $(\mathrm{km} / \mathrm{sn})$

do=Yoğunluk, $\left(\mathrm{g} / \mathrm{cm}^{3}\right)$

Deney sonuçları K numunelerinin ayrı ayrı hesaplanmış ve çizelgeler halinde verilmiştir (Çizelge 13).

Çizelge 13. K (Kasımiye Medresesi) numunelerinin elastisite modülü

\begin{tabular}{|c|c|c|c|}
\hline Numune & do $\left(\mathrm{g} / \mathrm{cm}^{3}\right)$ & Vo $(\mathrm{km} / \mathrm{s})$ & $\mathrm{Eu}\left(\mathrm{N} / \mathrm{mm}^{2}\right)$ \\
\hline $\mathrm{K}-1$ & \multirow{6}{*}{2,72} & 2,55 & $17,68 \times 103$ \\
\hline $\mathrm{K}-2$ & & 2,51 & $17,13 \times 103$ \\
\hline $\mathrm{K}-3$ & & 2,63 & $18,81 \times 103$ \\
\hline $\mathrm{K}-4$ & & 2,87 & $22,4 \times 103$ \\
\hline K-5 & & 2,46 & $16,46 \times 103$ \\
\hline K-6 & & 2,85 & $22,09 \times 103$ \\
\hline Ortalama & & 2,65 & $19,11 \times 103$ \\
\hline
\end{tabular}

\subsubsection{Sertlik değeri tayini}

Sertlik cisimlerin çizilmeye ve aşınmaya karşı gösterdikleri mukavemettir. Değişik yöntemlerle bulunur. Seramik yapılı malzemelerde Mohs sertlik cetveli uygulanır.

ITÜ Maden Fakültesinde yapılan ölçümler sonucunda Kasımiye Medresesi taş örneklerinin sertlik değerlerinin 2-3 arasında olduğu görülmüştür (Şekil 16).

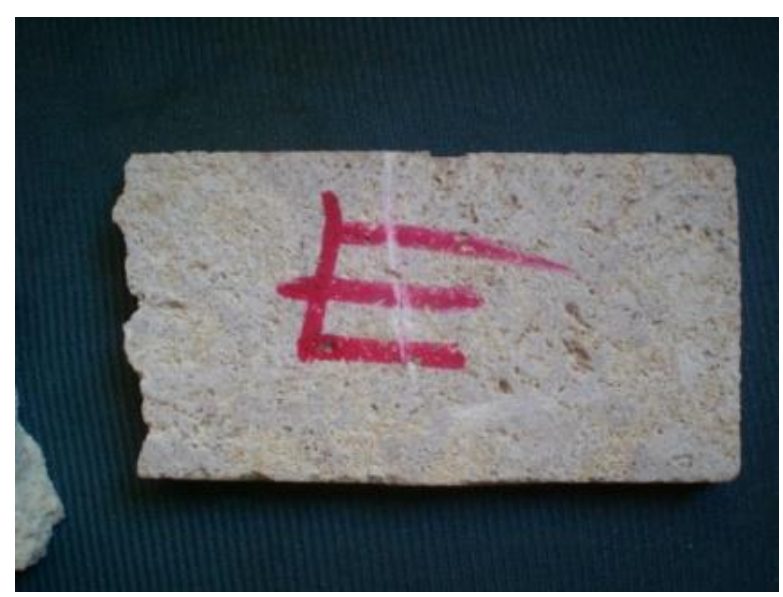

Şekil 16. Sertlik değeri tayini

\subsubsection{Mekanik özellik deney sonuçları}

Yapılan mekanik deneylerin sonuçları çizelgeler halinde aşağıda verilmiştir (Çizelge 14). Bu değerlerin yanı sıra yapı örneğinin sertlik değeri de 2-3 arasında ölçülmüştür. 
Çizelge 14. Kasımiye Medresesi örneklerinin mekanik özellikleri.

\begin{tabular}{|c|c|c|c|c|}
\hline ÖRNEK & $\begin{array}{l}\text { Ultrases Hızı } \\
(\mathrm{km} / \mathrm{s})\end{array}$ & $\begin{array}{l}\text { Eğilme } \\
\text { Dayanımı } \\
\text { (MPa) }\end{array}$ & $\begin{array}{ll}\text { Basınç } & 1 \\
\text { Dayanımı } & \\
\text { (MPa) } & \end{array}$ & $\begin{array}{l}\text { Basınç } \\
\text { Dayanımı } \\
\text { (MPa) }\end{array}$ \\
\hline K1 & 2,55 & 2,94 & 8,13 & 30,66 \\
\hline $\mathrm{K} 2$ & 2,51 & 4,05 & 9,37 & 36,85 \\
\hline $\mathrm{K} 3$ & 2,63 & 4,40 & 22,33 & 23,69 \\
\hline $\mathrm{K} 4$ & 2,87 & 6,77 & 16,99 & 25,49 \\
\hline K5 & 2,46 & 2,65 & 16,99 & 18,35 \\
\hline K6 & 2,85 & 3,56 & 26,40 & 18,60 \\
\hline Ortalama & 2,65 & 4,06 & 16,70 & 25,60 \\
\hline
\end{tabular}

\subsection{3. İç Yapı Analizleri}

Tarihi yapı örnekleri olan Kasımiye Medresesi deney numunelerinin içyapı özelliklerinin belirlenebilmesi için ince kesit, $\mathrm{X}$ ışın grafiği ve minerolojik-petrografik analizler yapılmıştır. $\mathrm{Bu}$ analizler ITÜ Maden ve Metalurji Fakültelerinin laboratuvarlarında yapılmıştır.

\subsubsection{Minerolojik ve petrografik analizler}

Kayacı oluşturan minerallerin mikroskop incelemesi ile belirlenmesidir. Bu amaçla, kütle halindeki örnekler yeterince sağlam ise doğrudan doğruya, dağılgan ise epoksi polimer içinde kalıplanarak ince dilimler halinde kesilir ve lam üzerinde aynı epoksi veya Kanada balsamı ile yapıştırıır. Çeşitli numaralarda zımpara ve parlatıcı tozlar ile 10-30 $\mu$ kalınlığa kadar inceltilerek hazırlanan ince kesitler polarizan mikroskop altında, minerallerin optik özelliklerinden yararlanarak gözlemlenir ve örneklerin içerdiği mineraller tanımlanır (TS EN 12407, 2002).

Kasımiye Medresesi örneğinin ince kesit fotoğraflarına göre; Bağlayıcısı karbonat çimentosundan oluşan taşın kalsit kristallerine ait görüntüsü çift nipol ışık ile Şekil 17 (a)' de tek nipol ışık ile Şekil 17 (b)'de görülmektedir. Bu görüntülere göre kalsit kristalleri sıkça görülmektedir. Kil, opak mineral ve fosil kalıntıları da yer yer görülmektedir.

Sonuç olarak numune tipik bir kireçtaşı örneğidir ve opak mineraller içermektedir. Aynı zamanda kil içeriğine sahiptir.

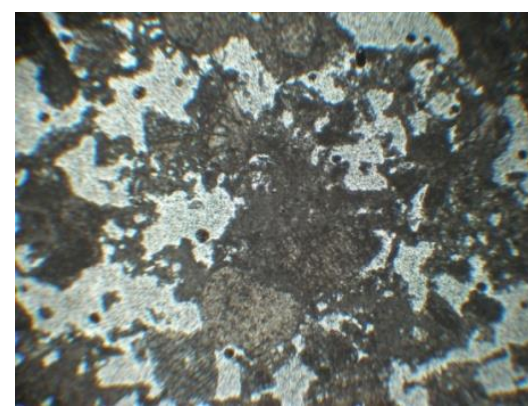

(a)

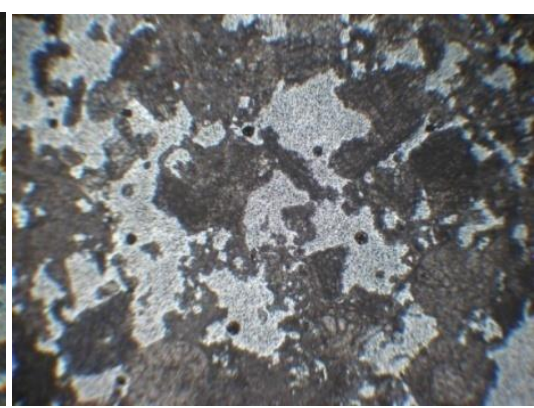

(b)

Şekil 17. (a, b) Kasımiye Medresesi örneğinin ince kesit fotoğrafları.

\subsubsection{Ince kesit analizleri}

Kasımiye Medresesi taş örneklerinden alınmış olan az miktardaki numuneler epoksi reçine içinde $24 \times 42 \mathrm{~mm}$ lameller üzerinde kalıplanarak, ince dilimler halinde kesilmiştir. Bu kesim işlemi 30 mikrona kadar aşındırma şeklinde olmuştur. Hazırlanmış olan ince kesitler Petrografi (kutuplandırılmış) mikroskop altında incelenerek içerdiği fosiller, örneklerin ayrışma dereceleri ve doku özellikleri gibi değerleri belirlenmiştir.

Ince kesit deney sonuçlarına göre; Kasımiye Medresesi'nden alınan taş örneği, bileşim itibariyle karbonat matrikslerinden oluşmaktadır. Örnek yer yer kil içeriğine sahiptir. Kalsit kristallerinden 
oluşmuş olan numune opak mineral saçınımları göstermektedir. Bileşiminde kısmen organizma (fosil) kalkınımları göstermektedir. Bu sonuçlara göre tipik bir mikritik kireçtaşı örneğidir. Bu taş örneği de Midyat taşı gibi kil içeriği fazla olan bir taş değildir.

\subsubsection{X-Işını analizleri}

Madde kristalinin sayısal özellikleri ve kimliğinin belirlenmesi için uygulanır. Taşlardaki çözünmüş tuz ve kil minerallerinin teşhisinde, harcın, çiçeklenme ürünlerinin ve siyah kirli kabuğun mineralojik tetkikinde kullanılır. Kırınım bilgileri iki basamakta yapılır; önce uygun sayısal algoritmalar ile bireysel safhada kimlik belirlenir sonra da uygun diğer yöntemlerle bu sayısal özellikler geliştirilir. Örnekler, önce homojen toz haline getirilir, özel koşullar altında X-ışın difraktometresi (kırınım ölçer) ile analiz edilir ve sonra örneklerin içerdiği mineraller tanımlanır. Bu deneyin sonucu aşağıdaki grafiklerde verilmiştir. (Şekil, 18).

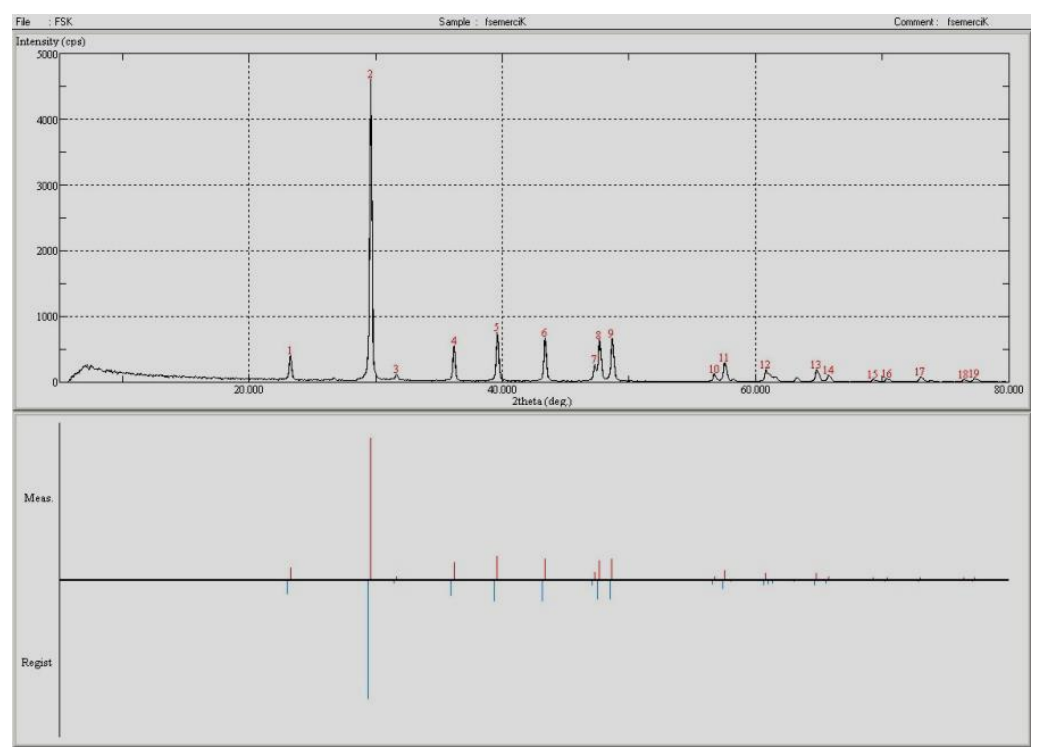

Şekil 18. Kasimiye Medresesi örneğinin X ışını analiz grafiği

Yapılan X ışını analizine göre, Kasımiye Medresesi örneğinin bileşiminin \% 96 oranında karbonattan oluştuğu görülmektedir. Yukarıdaki grafik kalsiyum karbonat bileşiminin örnekteki yoğunluğunu göstermektedir (Şekil 21). Örneğin yapısında magnezyum elementi de görülmektedir. Magnezyum ile bileşim kuran karbonatlara ise dolomit adı verilmektedir. Taşı dolomit olarak adlandırmak mümkündür.

\section{Karşılaştırma}

Sonuç olarak yukarıda yapılan deney çalışmaları ile tarihsel süreçte günümüze dek süregelmiş tarihi yapı örneklerinden olan Kasımiye Medresesi'nden elde edilmiş, Mardin kireçtaşı üzerinden değerlendirme yapmak mümkün olmaktadır. Numunelerin fiziksel, mekanik ve ince yapı değerleri, Mardin kireçtaşının zaman içindeki değişimini ve özelliklerindeki farklılıkları-benzerlikleri ortaya koymaktadır. Bu sonuçlar ışığında bu taşın dayanımı hakkında bir sonuç çıkarmak mümkündür.

Yapılmış olan minerolojik ve petroğrafik analizler, iç kesit analizleri ve $\mathrm{x}$ ışını grafiği değerleri bu yapı taşının tipik yöresel bir kireçtaşı örneği olduğunu göstermektedir. Bu taş dolomitik kireç taşı olarak adlandırılmaktadır. Yani taşın yapısında bağlayıcısı kalsiyum karbonat çimentosu olan kalsit kristalleri yoğun olarak bulunmaktadır. Ayrıca Medrese taş numunesinin asit kaybı \%81'dir. Bu durum Medrese taşının kil içeriğinin normal bir taşa göre daha fazla olduğunu göstermektedir.

Taşın su emme değerlerine bakıldığı zaman farklıııklar olduğu, bunun yanı sıra bu farkların çok yüksek değerler olmadığı görülmektedir. Numunelerin yoğunluk ve özgül ağırlıkları da birbirine yakındır. Fakat taşların kılcallık değerleri birbirinden farklı değerlere sahiptir. Bu durum taşın sert bölümlerinin sonuçlara belirli düzeyde etki ettiğini göstermektedir (Çizelge 15). 
Çizelge 15. Fiziksel özelliklerin karşılaştırılması

\begin{tabular}{|l|l|l|l|l|l|l|l|l|l|}
\hline Numune & Sk (\%) & Sh (\%) & $\begin{array}{l}\text { Skk } \\
(\%)\end{array}$ & $\begin{array}{l}\text { Skh } \\
(\%)\end{array}$ & $\begin{array}{l}\mathrm{dh} \\
\left(\mathrm{g} / \mathrm{cm}^{3}\right)\end{array}$ & $\begin{array}{l}\text { do } \\
\left(\mathrm{g} / \mathrm{cm}^{3}\right)\end{array}$ & $\begin{array}{l}\text { Porozite } \\
(\%)\end{array}$ & $\begin{array}{l}\text { Doymuşluk } \\
\text { derecesi } \\
(\%)\end{array}$ & $\begin{array}{l}\text { Kılcallık } \\
\text { katsayısı } \\
\left(\mathrm{g} / \mathrm{m}^{2} \text { vdk }\right)\end{array}$ \\
\hline $\begin{array}{l}\text { Kasımiye } \\
\text { Medresesi }\end{array}$ & 8,4 & 17,68 & 15,24 & 31,86 & 2,11 & 2,72 & 22,5 & 77,5 & 1589,59 \\
\hline
\end{tabular}

Mekanik özellikler karşılaştırıldığı zaman taş örneklerinin aynı sertlik değerine sahip olduğu görülmektedir. Ultrases hızlarında farklılıklar görülmektedir. Fakat bu farklılıklar da fazla değildir. Eğilme dayanımlarının normal değerlere sahip olduğu görülmektedir. Basınç dayanımlarında ise yüksek ve değişken değerler göze çarpmaktadır. Bunun sebebi ise homojen bir taş olmamalarından kaynaklanmaktadır. Taştaki sert bölümler mekanik özelliklerinin farklılığına sebep olmaktadır (Çizelge $16)$.

Çizelge 16. Mekanik özelliklerin karşılaştırılması

\begin{tabular}{|l|l|l|l|l|l|}
\hline Numune & $\begin{array}{l}\text { Ultrases } \\
\text { Hızı } \\
(\mathrm{km} / \mathrm{sn})\end{array}$ & $\begin{array}{l}\text { Eğilme } \\
\text { Dayanımı } \\
(\mathrm{Mpa})\end{array}$ & $\begin{array}{l}\text { Basınç 1 } \\
\text { Dayanımı } \\
(\mathrm{N})\end{array}$ & $\begin{array}{l}\text { Basınç 2 } \\
\text { Dayanımı } \\
(\mathrm{N})\end{array}$ & $\begin{array}{l}\text { Sertlik } \\
\text { Değeri } \\
(\mathrm{mohs})\end{array}$ \\
\hline Kasımiye Medresesi & 2,65 & 3,05 & 16,70 & 25,60 & $2--3$ \\
\hline
\end{tabular}

Bu sonuç ile birlikte taş örneklerinin fiziksel ve mekanik özelliklerinde aşırı derece olmayan farklar görülmektedir. Bileşim olarak aynı olan numunelerin bu özelliklerindeki değişme sebepleri çok çeşitli olabilir. Numunenin yapıdan alındığı bölüm, binanın işlevi ve taşın farklı dönemlere ait olması bu duruma etki eden sebeplerdendir. Özellikle farklı dönemlerde kullanılmış olan tarihi doku örnekleri günümüze dek yapı taşı olma niteliğini devam ettirmiştir. Bu örneklerin zamanla karbonatlaşması fiziksel ve mekanik özelliklerine yansımıştır.

\section{Sonuçlar}

Bu çalışma ile Mardin yöresinde bulunan kireç taşları hakkında deneysel verilere dayanan bir çalışma yapılmıştır. Mardin tarihi yapılarından olan Kasımiye Medresesi'nde kullanılmış kireçtaşlarının özellikleri deneysel olarak belirlenmiş, analiz edilmiştir. Burada Mardin'de kullanılmış ve kullanılacak olan kireçtaşının yapı taşı olarak kullanımın bilinçli ve yerinde olmasını sağlamak amaçlanmaktadır. Böylece tasarımın malzeme boyutunun çözüme yönelik ve sağlıklı olması istenmektedir.

Kasımiye Medresesi numunelerine analiz edilmesi ile fiziksel, kimyasal ve içyapı özellikleri tespit edilmiştir. Taşın çok fazla sert bölümler içermeyen bir heterojenliğe sahip olduğu görülmektedir. Bu durum da fiziksel özelliklerde görülmektedir. Özellikle su emme değerlerinin yüksek olması bu sebepledir. Sert bölümlerin etkisi mekanik özelliklere yansımaktadır. Bu durumun açıklanmasına en iyi örnek, mekanik deneylerde eğilme ve basınç dayanımlarının bazı değerlerindeki farklılıkların görülmesi ve yüksek değerlere sahip olmasıdır. Numunelerin bileşim olarak kalsit kristallerinden oluştuğu ve yapısında magnezyum ve demir içerdiği görülmektedir.

Yukarıda fiziksel ve mekanik özellikleri ile içyapı analizleri verilmiş olan Mardin kireçtaşının bir yapı malzemesi olarak kullanımının daha yerinde ve çevre koşullarının düşünüldüğü ortamlarda kullanımı hedeflenmektedir. Böylelikle bu malzemenin kullanım verimi artırılmış olmakla birlikte malzemenin özelliklerine uygun şartlarda kullanımı da sağlanmış olacaktır.

\section{Kaynaklar}

Alioğlu E. F. (2000). Mardin: Şehir Dokusu ve Evler, İstanbul.

Altun, A. (1971). Mardin'de Türk Devri Mimarisi, Gün Matbaası, İstanbul.

Borelli, E. and Urland, A. (1999). Laboratory Handbook: Conservation of Architectural Heritage, Historic Structures and Materials, ICCROM-UNESCO yayını, Roma. 
Dinç, O. (2004). Endüstriyel Hammaddeler Kireçtaşları, Dumlupınar Üniversitesi, Kütahya.

Erguvanlı, K. (1955). Türkiye Mermerleri ve İnşaat Taşları, iтü yayını, İstanbul.

Yüzer, E. (1997). Türkiye'nin Doğal Taşları, Gün Matbaası, İstanbul.

Gabriel, A. (1933). “Mardin ve Diyarbakır Vilayetlerinde İcra Olunmuş Bir Arkeologya Seyahati Hakkında Rapor", T.T.A.E. Dergisi, Ankara.

Gökaltun, E. (1997). Atmosferik Kirleticilerin Kuru ve Islak Çökelme Mekanizmalarının Kireçtaşlarındaki Parlaklık Kaybına Etkisi, Doktora Tezi, íT̈̈, İstanbul.

Meriçboyu, E. (1988). Kireçtaşı ve Dolomitlerin Akışkan Yatakta Ufalanma Özelliklerinin İncelenmesi, Yüksek Lisans Tezi, iтÜ, İstanbul.

Göyünç, N. (1969). XVI. Yy'da Mardin Sancağı, İstanbul.

Kocataşkın, F. (2000). Yapı Malzemesi Bilimi: Özellikler ve Deneyler, iтü, İnşaat Fakültesi, İstanbul.

TS EN 1925. (2000). Doğal Taşlar, Deney Metotları, Kılcal Etkiye Bağlı Su Emme Katsayısının Tayini, Türk Standartları Enstitüsü, Ankara.

TS 699. (1979). Doğal Taşlar, Deney Metotları, Türk Standartları Enstitüsü, Ankara.

TS EN 14579. (2006). Doğal Taş Deney Metotları-Ses Hızının İlerlemesinin Tayini, Türk Standartları Enstitüsü, Ankara.

TS EN 12372 (2003). Doğal Taşlar, Deney Metotları, Tek Eksenli Yük Altında Eğilme Dayanımı Tayini, Türk Standartları Enstitüsü, Ankara.

TS EN 1926. (2000). Doğal Taşlar, Deney Metotları, Basınç Dayanımı Tayini, Türk Standartları Enstitüsü, Ankara.

TS EN 14146. (2004). Doğal Taşlar Deney Metotları-Dinamik Elastisite Modülünün Tayini, Türk Standartları Enstitüsü, Ankara.

TS EN 12407. (2002) Doğal Taşlar, Deney Metotları, Petrografik İnceleme, Türk Standartları Enstitüsü, Ankara.

TS EN 1936 (2001). Doğal Taşlar, Deney Metotları, Gerçek Yoğunluk, Görünür Yoğunluk, Toplam ve Açık Gözeneklilik Tayini, Türk Standartları Enstitüsü, Ankara.

TS EN 12370 (2001). Doğal Taşlar, Deney Metotları, Tuz Kristallenmesine Direncin Tayini, Türk Standartları Enstitüsü, Ankara. 